Jurnal Bisnis dan Manajemen, Volume 22, No. 1, March 2021, p. 51-64

\title{
DETERMINANTS OF CAPITAL STRUCTURE'S ADJUSTMENT SPEED: EMPIRICAL ANALYSIS OF REAL ESTATE, PROPERTY, AND CONSTRUCTION FIRMS
}

\author{
Subiakto Soekarno ${ }^{1}$, Eggy Muhammad Prayoga ${ }^{2}$, Indra Yudha Mambea ${ }^{3}$ \\ 1,2,3 Institut Teknologi Bandung, Indonesia
}

\begin{abstract}
This study explored the determinants of capital structure, optimal capital structure, and adjustment speed in real-estate, property, and construction firms in Indonesia. It conducted a quantitative analysis of the annual report of 25 listed firms by employing a generalized method of moment approach with panel data to estimate the result. Results showed that the determinants of capital structure, such as profitability, tangibility, size, and liquidity, have a negative impact on leverage. By contrast, a non-debt tax shield has a positive impact. Based on the regression result, firms have an optimal capital structure target with a yearly adjustment speed of $80 \%$. Furthermore, calculation of optimal target structure shows that firms require approximately three years to meet the discrepancy between their current capital structure and the targeted capital structure.
\end{abstract}

Keywords: adjustment speed, capital structure, generalized method of moment, panel data

\section{DETERMINAN KECEPATAN PENYESUAIAN DARI STRUKTUR MODAL: ANALISIS EMPIRIS PADA PERUSAHAAN-PERUSAHAAN REAL ESTATE, PROPERTI, DAN KONSTRUKSI}

\begin{abstract}
ABSTRAK
Penelitian ini mengeksplorasi faktor-faktor penentu struktur modal, optimal struktur modal, dan juga kecepatan penyesuaian pada perusahaan real estate, properti, dan konstruksi di Indonesia. Analisis kuantitatif yang digunakan berbasiskan data laporan tahunan dari 25 perusahaan yang tercatat di bursa efek Indonesia dengan mengaplikasikan model regresi data panel generalized method of moment. Hasil penelitian menunjukkan bahwa profitabilitas, tangibilitas, ukuran perusahaan, dan likuiditas, berpengaruh negatif terhadap leverage. Sebaliknya, non-debt tax shield berdampak positif terhadap leverage. Diketahui pula berdasarkan hasil regresi bahwa perusahaan real estate, properti, dan konstruksi di Indonesia memiliki target struktur modal yang optimal dengan estimasi penyesuaian tahunan sebesar 80\%. Kemudian, hasil kalkulasi pada target struktur yang optimal menunjukkan bahwa perusahaan membutuhkan kirakira tiga tahun agar bisa menutup gap antara struktur modal saat ini dan struktur modal yang ditargetkan.
\end{abstract}

Kata-kata Kunci: kecepatan penyesuaian, struktur modal, metode generalized of moment, data panel

${ }^{3}$ Korespondensi: Indra Y. Mambea, Sekolah Bisnis dan Manajemen, Institut Teknologi Bandung. Jln. Ganesha 10, Bandung, Indonesia. Email: indra.yudha@sbm-itb.ac.id 
Jurnal Bisnis dan Manajemen, Volume 22, No. 1, March 2021, p. 51-64

\section{INTRODUCTION}

Indonesia considers infrastructure as one of its accelerators to maximize the full potential of the country's economy, stimulate GDP, provide jobs, and reduce poverty (Negara, 2016). Efficient infrastructure decreases distribution costs and increases the standard of living by producing affordable goods and services. Infrastructure entails substantial benefits to the country, such as access to improved educational services and health and enhanced living conditions of the impoverished class, and fostering great social as well as economic mobility (Asia Development Bank, 2017). State-owned enterprises (SOEs) are supporting this development project through investments in infrastructure (OECD, 2018). Various infrastructures, such as new highways, bridges, dams, and power plants, have been built massively in several regions in Indonesia. Infrastructure development may be the key to expanding connectivity and encouraging interregional competitiveness throughout the archipelago. In implementing this agenda, the government provides funding to support SOEs (Nugroho, 2019). In addition to SOEs, several private companies that take part in real-estate, property, and construction sectors are also involved in executing this plan. These companies control administrative, technical, and financial matters. As executors of vital projects, firms are facing the rumination of the precise formulation for their financing. Loaning from banks, issuing bonds, and collaborating with private companies are efforts that came as consequences for said the piece of work. These financing in turn may distort capital structure.

The primary goal of a firm is to generate value for the company's owners (Keown et al., 2017). However, finance managers of companies play an essential role in the formulation of the capital structure (Chadha and Sharma, 2015). In addition, managers are responsible for funding decisions related to the combination of ordinary and preferred shares, including debt. Therefore, exploring how best to attain the optimal capital structure to achieve the goals of SOEs is crucial for managers. In terms of funding, inaccurate decisions of firms can potentially affect capital cost, resulting in low profitability. Determining the composition of capital and debt in the context of its utilization as a corporate funding source is often associated with capital structure (Thi et al., 2017). An imprecise decision in determining capital structure may lead to financial distress or even bankruptcy. Given that many variables affect the capital structure incorporated within a firm's characteristics (Nha et al., 2016), analyzing the factors that strongly affect the capital structure is vital given that decisions for capital structure vary across the industry.

Several studies show that variables of firms characteristics are important in decisions on capital structure. Padrón et al. (2005) observed the determinant factors of leverage in Spain. Serrasqueiro et al. (2016) found several variables that influence the capital structure of small 
Jurnal Bisnis dan Manajemen, Volume 22, No. 1, March 2021, p. 51-64

enterprises in Portuguese. Mota and Moreira (2017) conducted a research on the determinants of capital structure in Angola. In the same year, Sofat and Singh (2017) examined the factors that influence the capital structure, specifically in manufacturing firms in India.

Apart from the above studies, certain studies analyzed the target of capital structure as well as adjustment speed. In terms of the target of capital structure, Graham and Harve (2001) revealed that approximately $81 \%$ of firms possess a debt ratio target or a range of capital structure target. Getzmann et al. (2014) also revealed that the speed adjustment of the average Asian firm is $31 \%$. By contrast, Syahara and Soekarno (2015) found that Indonesian firms have a speed adjustment of $26 \%$ to $39.8 \%$.

Related to the massive infrastructure in Indonesia that is run by SOEs and private companies, this study focuses on firms drawn from listed real-estate, property, and construction industries. We construct three research objectives to answer the previously stated objectives. First, this work explores the variables that influence the capital structure of companies that are listed in the real estate, property, and construction industry. Second, it examines if the target of optimal capital structure exists. Third, it seeks the adjustment of companies.

\section{LITERATURE REVIEW}

\section{Capital Structure}

Capital structure pertains to the magnitude of equity and debt capital distributed by a company to defray assets (Mota and Moreira, 2017). Although debts and equities have positive outcomes, several drawbacks of their usage become a multitude of issues in corporate finance. Modigliani and Miller (MM) in 1963 developed hypotheses that the tax benefits of debt enable to elevate the value of the company and lower the price of utilizing debt capital. Several studies on capital structure exist. Jensen and Meckling (1976) concluded that debt can generate benefits for firms. The interest paid on debt can also be considered during its maturity compared with the payment of dividends. The dividend payment (DP) often fluctuates and relies on profitability. It is due to interest on debts is taxdeductible spending and choosing debt means generating a tax shield.

Meanwhile, debt can generate leverage. Leverage can expand the company's operations, thus enhancing profit and stock value. Conversely, the overusage of debt also contains risks. An increment in the magnitude of debt entails problems for the company, such as the possibility of financial distress or bankruptcy. Morever, debt potentially leads to losses if the company does not perform well due to loan interests. Using debt to finance business must optimize benefits from debts and minimize risks as well (Horne and Wachowicz, 2008). 
Jurnal Bisnis dan Manajemen, Volume 22, No. 1, March 2021, p. 51-64

Given that the company's objective is to decrease their capital cost, interest rate and magnitude of debt are crucial in influencing their optimal capital structure (Brigham and Houston, 2013). Rawley et al. (2010) argued that a firm with return on invested capital and revenue growth that are higher than its weighted average cost of capital would be beneficial. Conversely, the magnitude of debt and interest rate play a significant role in influencing capital cost. Therefore, a company can attain its optimal capital structure by adjusting not only the magnitude of debt but also the interest.

Numerous studies with empirical evidence regarding the variables explaining the capital structure of firms exist in several countries. However, no concesus is reached on the significant determinants of capital structure in developed as well as developing economies (Sofat and Singh, 2017).

Several studies, such as Frank and Goyal (2009), found that profitability is linked to leverage, where tangibility is gauged by the fixed asset to total asset. Meanwhile, Booth et al. (2001) revealed that tangibility has a relationship with leverage. Another variable, namely, growth is considered using the market-to-book value of equity, similar to research of Deesomsak et al. (2004). Growth is related to leverage. Liquidity is measured using the current assets without inventory to current liabilities. Sangeetha and Sivathaasan (2013) observed a positive but weak correlation between liquidity and leverage. Size is measured using total assets in natural logarithm form. Frank and Goyal (2009) who studied capital structure decision found that size is related with leverage. Non-debt tax shield (NDTS) is often measured using depreciation to total assets. Serrasqueiro et al. (2016) found that NDTS is correlated with leverage. Lastly, dividend variable is often measured by dividend to net income. Sangeetha and Sivathaasan (2013) also found that dividend policy affects leverage.

In explaining financial decisions of firms, pecking-order theory (POT) is often considered (Frank and Goyal, 2009). This theory states that financial cost grows with asymmetric information. Myers and Majluf (1984) posited that POT explains that firms prefer internal financing as the first choice to debt and equity. Asymmetry of information is the reason firms put internal source of financing as their priority. This scenario occurs because managers possess information related to firms's fair with more precision than investors as well as other stakeholders. As such, managers prefer equity as the last resort to prevent disparity between firms and market value. Meanwhile, Trade-off-Theory (TOT) is one of the most influential concepts of capital structure. A balanced condition among tax savings from debt, financial distress, and decrease in agency and bankruptcy cost is the main focus of this theory (Myers, 1984). This notion is connected to Modigliani and Miller's theory, TOT proposes the modification of MM proposition through the benefits of tax shield are off-set by the financial cost distress as well as 
agency cost. Many studies divided TOT into static and dynamic theories.

The static model states that the optimal capital structure of a company can be attained by comparing the cost against the benefit of debt and equity usage (Danso and Adomako, 2014). Meanwhile, the dynamic model argues that financing decisions of a company depends on the margin of financing that said company expects in the next period given that the optimum option of the current finance relies on what is expected to obtain an optimal value in the following period. Therefore, relying on the company's expectation, debt or equity finance is possible (Luigi and Sorin, 2009). Meanwhile, dynamic TOT allows the role of required times but does not consider one-period analysis. It requires the expectations and adjustment of cost.

Various prominent variables are involved in exploring the determinants of capital structure, namely profitability, tangibility, growth opportunity, liquidity, size, NDTS, and dividend policy. By using EBITDA divided by the book value of assets as proxy for profitability, Rajan and Zingales (1995) showed an inverse relationship between leverage and profitability. Several proxies were added previously, namely, operating income to total assets and operating income to sales ratio (Titman and Wessels, 1988) and return on assets (ROA) (Wiwattanakantang, 1999).

Chen (2004) confirmed a positive correlation between leverage and tangible asset in 88 Chinese publicly listed companies. Meanwhile,
Proença et al. (2014) noted that assets in tangible form can be reflected as proxy of collateral to the lender. Tangible assets affect debt level. This relationship influences borrowing decision and tangible assets make higher value in the event of bankruptcy than firms that excessively rely on intangibles. Deesomsak et al. (2004) revealed that a strong inverse relationship exists between growth and leverage. This relationship is formed because high growth firms tend to use less debt to prevent possibility restrictions imposed by lenders. Mota and Moreira (2017) noted that liquidity provides information on whether firms can meet their shortterm financial responsibility. Deesomsak et al. (2004) and Sangeetha and Sivathaasan (2013) applied the variable of liquidity as proxy for debt level, and they found that liquidity and capital structure are associated. However, POT predicts an adverse relationship between liquidity and leverage because liquid firms tend to borrow less.

Wiwattanakantang (1999) pointed out that larger companies may have an advantage over smaller companies in terms of obtaining credit. Sayılgan et al. (2006) added that higher capacity in borrowing entails better access to capital markets as well. This conclusion is consistent with TOT that the bigger the firms, the greater the debt level. Meanwhile, Cloyd et al. (1997) revealed that the presence of NDTS suggests an alternate way to reduce income taxes as well as able to alleviate the benefit of debt tax shields. Interest tax shields are not the sole solutions to lower the firm tax burden. Rozeff (1982) observed that paid dividends may 
potentially reduce the magnitude of free cash flow given that payments of dividends decrease the free cash flow. Hence, firms use debt as alternative financial sources. This finding is consistent with POT that suggests that payout ratio positively affects debt.

To sum up, we provide a table of hypotheses and their sources from previous studies as follows.

Table 1. Hypotheses

\begin{tabular}{lcl}
\hline $\begin{array}{l}\text { Dependent variable: } \\
\text { Leverage (LEV) }\end{array}$ & Hypothese & \multicolumn{1}{c}{ Previous study } \\
\hline Profitability (PRO) & $(-)$ & Frank and Goyal, (2009) \\
Tangibility (TANG) & $(+)$ & Frank and Goyal, (2009) \\
Growth (GRO) & $(-)$ & Deesomak et al. (2004) \\
Liquidity (LIQ) & $(+)$ & Sangeetha and Sivathaasan, (2013) \\
Size (SIZE) & $(+)$ & Frank and Goyal, (2009) \\
Non-debt tax shield (NDTS) & $(+)$ & Serrasqueiro et al. (2016) \\
Dividend Policy (DP) & $(+)$ & Sangeetha and Sivathaasan, (2013) \\
\hline
\end{tabular}

\section{Target Capital Structure and Speed of Adjustment}

TOT presumes that the manager appraises the costs and benefits of any possible scheme for financing. However, an optimal capital structure for a single period assumes that firms, in any event, balances their capital structure toward the optimal target capital structure provided by static TOT as the solution. By contrast, dynamic TOT considers time, expectations, and adjustment costs (Fischer et al., 1989). On the basis of the dynamic one, companies generate partial adjustments toward the optimum target capital structure over time where zero value in cost of adjustment indicates that the target would be instantaneous (Faulkender et al., 2012). In addition, dynamic TOT implies the existence of target capital structure and assumes that companies perform financial decisions to lower the deviation from target cost (Chang and Dasgupta, 2009). However, on the basis of the framework of static TOT, Miller (1977) revealed that an optimal capital structure would never exist. Bankruptcy costs are "insignificant," and tax advantage from debt at the company level would be exactly set-off by the tax drawback of debt at the private level. Haugen and Senbet (1978) added that the costs of bankruptcy are significantly undersized to substitute the tax advantage through its debt financing. After studying the financial decisions of US corporations, Jalilvand and Harris (1984) suggested that dynamic TOT asserted that a company's financing behavior is indicated by the partial adjustment of financial targets in the long term. A similar result is confirmed by Graham and Harvey (2001), who revealed that about $81 \%$ of CFOs have a target debt ratio.

\section{METHODS}

Frank and Goyal (2009) developed a hypothesis for the target adjustment framework. The foundation of this frame focuses on the speed of adjustment toward the target capital structure that relies on the costs of adjustment and the costs of deviating from the target (Faulkender et al., 2012). When adjustment costs are high, its speed of adjustment is slow. However, when the cost of deviating from the target is also high, the speed of adjustment is fast. In this study, instead of employing the static model, the dynamic model is applied to investigate the presence of optimal target capital structure as 
the static model presumed that no cost of adjustment exists as well as target optimal capital structure reffered to the dynamic partial adjustment model. This study posits that severals predictor variables determine the optimal leverage (Leverage ${ }^{*}, \mathrm{t}, \mathrm{)}$ as follows:

Lev $*_{i, t}=\left(\right.$ Profitability $_{i, t-1}$, Tangibility $_{i, t-1}$, Growth $_{i, t-1}$,

$$
\text { Liquidity } \left._{i, t-1}, \text { Size }_{i, t-1}, N D T S_{i, t-1}, D P_{i, t-1}\right)
$$

The $i$ denotes the companies, and $t$ represents the time series from 2009 until 2018. The dependent variable of model $i$ at period $t$ $\left(L e v_{i, t}\right)$ is no longer equivalent to the optimal leverage $\left(\operatorname{Lev} *_{i, t}\right)$, given that we predict that the adjustment costs exist, which is assumed by $L e v_{i, t}$ $\neq L e v *_{i, t}$. Given the existence of costs of adjustment, companies only generate partial adjustments. As in this research, $\delta$ is expected to be less than 1, and the partial adjustment can be stated as:

$$
L e v_{i, t}-L e v_{i, t}=\varphi\left(L e v *_{i, t}-L e v_{i, t-1}\right)+\varepsilon_{i, t-1}
$$

By assuming that $0<\varphi \leq 1, \varphi$ represents the adjustment speed to eliminate the disparity between a company's preference leverage adjustment and its actual leverage adjustment (Flannery \& Rangan, 2006), while $\varepsilon_{i, t}$ represents the idiosyncratic error term (Lemma \& Negash, 2014). We also propose that the adjustment speed coeficient does not change across companies and over time with the general speed of adjustment estimated for observed companies (Ameer, 2010). The determinants of companies that represent this behavior is expressed by the Equation (2.2) by referring Haron (2016) as follows:

$$
L e v *_{t, i}=\sum_{n=1}^{N} \beta_{k} X_{i, t}+\varepsilon_{i, t}
$$

Combining equations (2.1) and (2.2), will be,

$$
L e v_{i, t}=L e v_{i t-1}+\varphi\left(L e v *_{i t}-L e v_{i t-1}\right)
$$

Partly multiplying the equation by $\varphi$, we obtain:

$$
\begin{array}{r}
\operatorname{Lev}_{i, t}=\operatorname{Lev}_{i t-1}+\varphi L e v *_{i t}-\varphi_{i t} \operatorname{Lev}_{i t-1} \\
\operatorname{Lev}_{i, t}=(1-\varphi) \operatorname{Lev}_{i t-1}+\varphi\left(\sum_{n=1}^{N} \beta_{k} X_{k, i, t}+\varepsilon_{i, t}\right) \\
\operatorname{Lev}_{i, t}=(1-\varphi) \operatorname{Lev}_{i t-1}+\sum_{n=1}^{N} \varphi \beta_{k} X_{k, i, t}+\delta \varepsilon_{i, t}
\end{array}
$$

Following the model in the dynamic capital structure form developed by Soekarno et al. (2014), we use Equation (2.6) to estimate the result.

We employ a purposive sampling method as our population covers Indonesian firms that are listed in Property, Real Estate and Construction sector and execute Initial Public Offering (IPO) before 2010. Our sample consists of 25 that have a specified characteristic with the highest market capitalization and trading volume.

However, instead of using random effect panel regression, we employed the Generalized Method Moment (GMM) developed by ArellanoBond. This method offers benefits that can overcome crucial econometrics problems, that is, fixed effects and endogeneity of explanatory variables. Furthermore, the model can avoid dynamic panel bias (Abdeljawad et al., 2013). Deesomsak et al. (2004) and Lemma and Negash (2014) showed that the GMM approach is a relevant approach to regress the model (2.6), whereas random-effects or fixed-effects models can potentially generate inconsistency and bias in 
the regression result (Ramjee and Gwatidzo, 2013). Therefore, GMM is performed for the purpose of regression. In addition, the adjustment speed of companies to target leverage is also regressed from model (2.6), which is represented by $\varphi$. We employ the GMM approach introduced by Arellano and Bond, (1991) to obtain the estimator that affects the capital structure. As the predicted variable, leverage is defined as total debt to total equity. An unbalanced panel data is used due to insufficient information provided by the companies. To obtain the estimation from a set of exogenous variables that determine the capital structure, we run a regression model as follows:

Lev $_{i, t}=(1-\varphi) L E V_{i t-1}+\left(\varphi * \beta_{1}\right) P R O_{i, t-1}+\left(\varphi * \beta_{2}\right) T A N G_{i, t-1}+(\varphi *$ $\left.\beta_{3}\right) \operatorname{GRO}_{i, t-1}\left(\varphi * \beta_{4}\right) L I Q_{i, t-1}+\left(\varphi * \beta_{5}\right) \operatorname{SIZE}_{i, t-1}+\left(\varphi * \beta_{6}\right) N D T S_{i, t-1}+$ $\left(\varphi * \beta_{7}\right) D V_{i, t-1}$

To estimate the speed of adjustment, $\varphi$ is applied from Equation (2.6). In addition, this study employs $(1-\varphi)$ to obtain the estimation of the gap. After determining the speed of adjustment, an equation from Soekarno et al. (2016) was applied to explore the time required to attain the capital structure target as follows:

$$
n=\frac{\log (1-Y n)}{\log (1-\varphi)}
$$

where $Y_{n}$ represents capital structure target, and $\delta$ is speed of adjustment.

\section{RESULTS AND DISCUSSION}

Before performing data analysis, descriptive statistics result is displayed. The data comprise 25 real estate, property, and construction firms for ten years from 2008 to 2018. However, because a portion of the data is not available, we included only 258 to 260 observations. The collected data cover the following variables. Leverage as the dependent variable and profitability, tangibility, growth, liquidity, size, NDTS, and DP as independent variables. All variables are arranged in one regression model.

Table 2. Descriptive Statistics

\begin{tabular}{ccccc}
\hline & Mean & St. Dev & Minimum & Maximum \\
\hline LEV & 0.26 & 0.24 & -2.09 & 1.23 \\
PRO & 0.17 & 1.12 & -0.05 & 17.64 \\
GRO & 1.63 & 1.83 & -11.30 & 12.77 \\
TANG & 0.50 & 0.23 & 0.04 & 0.98 \\
LIQ & 1.20 & 2.54 & -1.16 & 36.06 \\
NDTS & 0.03 & 0.25 & 0 & 3.56 \\
SIZE & 22.64 & 1.24 & 13.71 & 25.55 \\
DP & 0.18 & 0.51 & 0 & 5.95 \\
\hline
\end{tabular}

Source: Author's calculation using STATA 14

Table 2 shows that the firm leverage in real estate, property, and construction firms on an average 0.26 . Profitability is 0.17 . Growth varies from -11.30 to 12.77 . Tangible ranges from 0.04 to 0.98 . Liquidity ranges from -1.16 to 36.06 . NDTS and DP show the same value 0 , whereas size has no negative or even 0 value. It shows on an average 22.64. To answer the research questions, we employ the GMM method for estimating parameters in the econometric model. Table 3 presents the result of the estimation. 
Jurnal Bisnis dan Manajemen, Volume 22, No. 1, March 2021, p. 51-64

Table 3. GMM Estimation Result

\begin{tabular}{cccc}
\hline Variable & Coef. & z-stat & Prob \\
\hline$L E V_{i, t-1}$ & 0.203 & 5.29 & $0.000 * * *$ \\
$P R O_{i, t-1}$ & -1.851 & -5.28 & $0.000 * * *$ \\
$G R O_{i, t-1}$ & 0.023 & 0.79 & 0.428 \\
$T A N G_{i, t-1}$ & -1.889 & -1.90 & $0.057^{*}$ \\
$L I Q_{i, t-1}$ & -0.030 & -1.88 & $0.061^{*}$ \\
$N D T S_{i, t-1}$ & 1.865 & 5.17 & $0.000^{* * *}$ \\
$S I Z E_{i, t-1}$ & -0.026 & -0.41 & 0.682 \\
$D P_{i, t-1}$ & 0.036 & 0.43 & 0.666 \\
\hline$* * * * * *$ refer to the significance level from $1 \%, 5 \%$, to $10 \%$, respectively.
\end{tabular}

We report $z$-statistics that are robust to heteroskedasticity in table 3 . Arrellano-Bond in first-differenced errors is also run as a test for zero autocorrelation. Our result shows prob 0.336 for order 1 and 0.341 for order

2 with under $\mathrm{H}_{0}$ : no autocorrelation, we do not reject the null hypothesis. A

Wald test is also applied, which shows prob 0.000 . Hence, the null hypothesis is rejected, and the endogenous regressors are relevant.

Source: Author's calculation using STATA 14

This study employs GMM with a one-step method to explore the significant variables that influence the capital structure. In this model, the coefficient of the lagged dependent variable is an explanatory variable for the recent estimation of the response variable. We employ lagged in the dependent variable (LEVL1) as the instrument variable as well as one of the regressors. The regression results shown in Table 3 confirm that the lagged of profitability and lagged of NDTS of the variables have a $p$-value below 5\%, while lagged of tangibility, lagged of liquidity have a $p$-value below $10 \%$. These findings lead to the rejection of the null hypothesis of these variables being statistically insignificant.

Profitability negatively influences capital structure. This conclusion agrees with POT, which notes that profitable firms are likely to utilize internal sources to finance their potential or current activities. Myers (1984) claimed that if the requirements for the funds cannot be achieved, then low-profit companies rely on debt and then issue equity securities. This conclusion contradicts TOT, which expects that profitability positively affects leverage. Therefore, profitable firms tend to utilize internal sources and rely less on debt financing given that they have funding. This result is also similar to the study of Frank and Goyal (2009).

In line with POT, which expects a positive relationship between growth and capital structure, our result shows a statistically insignificant but positive relationship between capital structure and growth. According to this theory, when facing a lack of internal funds, firms that have high growth are likely to utilize leverage (Ross et al., 2008). Although the regression coefficient is positive, the $p$-value is not statistically significant. This may indicate that growth in the Real Estate, Property, and Construction companies is not the main factor in increasing leverage. The more a company grows, the higher the demand for funding needs. However, the growth of the company does not directly impact the leverage.

Consistent with POT that expects a negative correlation between capital structure and liquidity, our finding reveals a statistically significant negative relationship between capital structure and liquidity. High-liquidity companies tend to be high in current assets, which they can use as capital expenditure. However, this finding contradicts TOT, which expects that liquidity positively affects capital structure given that highliquidity firms are likely to utilize long-term debt 
and are at low risk of financial distress. Therefore, high-liquidity firms tend to have low leverage. The magnitude of their current assets can be allocated for capital expenditure.

Our result finds that tangibility negatively affects capital structure. Although this conclusion contradicts TOT, our finding is in harmony with POT, which expects that tangibility negatively affects capital structure. This finding is also in agreement with the result obtained by Booth et al. (2001), who claimed that an opposite association exists between tangibility and leverage in firms in developing countries. Therefore, firms are likely to rely more on internal financing or equity than debt, and fixed assets may not serve as collateral.

As stated by TOT, NDTS negatively affects capital structure. Hence, that high NDTS firms receive an advantage of tax shield from depreciation and amortization. In addition, firms tend to show low-magnitude long-term debt. Nevertheless, we find that a positive relationship exists between capital structure and NDTS. As shown in Table 3 the coefficient is significant at either $1 \%$ or $5 \%$ level of significance. The positive relationship between NDTS and capital structure can be construed as such; tax reduction emanate depreciation unable perfectly compensate tax benefit from debt financing among real-estate, property, and construction firms in Indonesia implying that firms may seek a tax shield advantage from both financing methods.

TOT states that sizeable firms are likely to have a higher magnitude of long-term debt than smaller firms due to low cost of bankruptcy. Agency costs are also in line with TOT. The bigger the firm, the higher the probability of receiving debt from banks or other financial institutions because of the company's reputation. Conversely, the conclusion of POT contradicts this finding. Size and leverage have the opposite association. Perhaps the asymmetric information between capital market and insider is low in big companies expressing small in equity financing costs. Furthermore, larger firms are expected to be more capable of using internal financing to finance projects or to involve in investments compared with smaller firms. Size and leverage have the opposite association. This result is in sync with POT, which indicates that the bigger the firm the more the firm prefers to use internal sources as opposed to debt.

Referring to TOT, an inverse relationship exists between DP and capital structure. Debt utilization provides a solution for free cash flow problems by lowering the agency cost as well as allows tax shield benefits. Furthermore, an insignificant effect of dividend on leverage may reveal how firms in this sector in Indonesia do not need to take the benefits from debt or equity only. However, the companies attempted to balance the benefits from equity and debt, which possibly resulted in optimization.

Some of our findings indicate the coefficient results are in line with theory but some differ. These differences may probably have resulted due to a more complex relationship variables in the dynamic model. Frank and Goyal 
(2009) revealed that the correlation between variables could change over a period of time from short to long term.

Our estimation procedure involves optimal capital structure output as well as considers the adjustment speed. On the basis of our estimation employing the model of dynamic capital structure, we find that the leverage of the previous year significantly and positively affected the leverage of the current year. By using 95\% confidence level, we can examine the probability value of its $z$-test that shows lower than 0.05 .

Table 3 shows that LEV1 is positively associated with LEV, and its coefficient is significant at the $1 \%$ level of significance. Hence, firms have optimal capital structure and adjust toward it within an exact magnitude of speed. In addition, the parameter of lagged leverage shows 0.203 , which is $(1-\varphi)$. As a result, the adjustment speed $(\varphi)$ is 0.797 . Target leverage adjustment is presumed to be $99 \%$ with $1 \%$ level of tolerance. Accordingly, firms are nearing 0.797 or $80 \%$ disparity and must meet the remaining 20\% between the recent capital structure and its optimal target. By employing Equation (2.8), the speed of adjustment period $(n)$ is 2.89. Therefore, companies require less than three periods to meet the disparity between recent capital structure and its target.

Getzmann et al. (2010) revealed that the capital structure in Asia's firms showed on average $31 \%$ of speed of adjustment. Meanwhile, in Indonesia, Syahara and Soekarno (2015) showed ranges from $26 \%$ to $39.8 \%$ of speed of adjustment. As the adjustment speed toward optimal target capital structure is determined by the cost of adjustment, the speed of adjustment of $80 \%$ in firms signifies that the adjustment cost is low. Thus, the advantage of optimal capital structure can be potentially received at low price. Ultimately, the adjustment speed of firms is faster than prior studies.

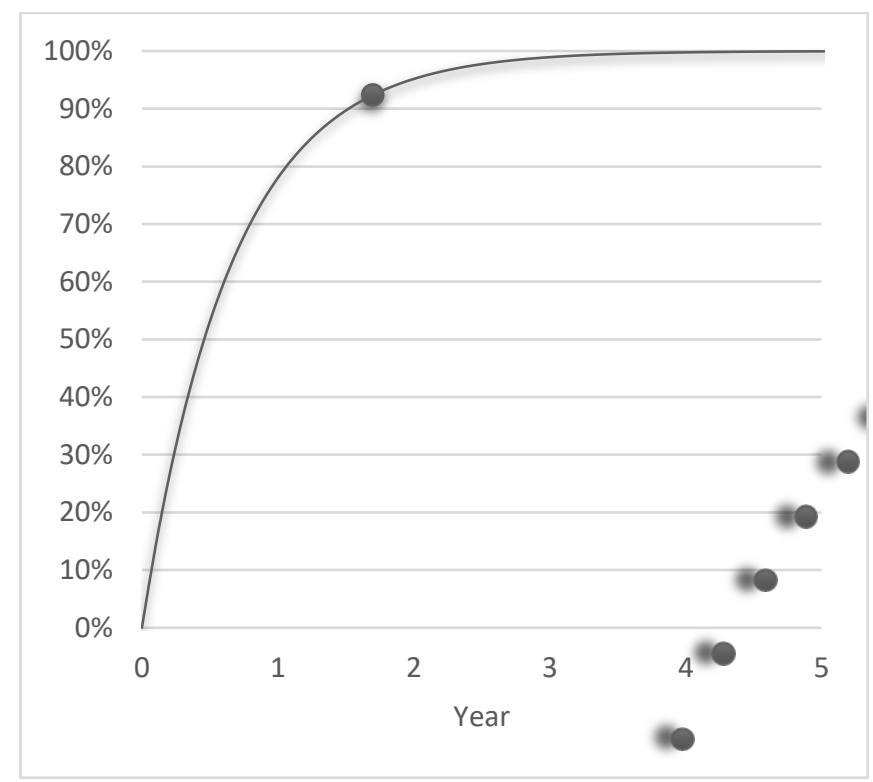

Figure 1. A geometric simulation of partial adjustment for capital structure.

Source: Author's calculation using Microsoft Excel 365

Figure 1 illustrates a simulation of partial adjustment for capital structure in real-estate, property, and construction firms in Indonesia. By using geometric approach, our calculation shows a convergence the disparity between the current and the targeted capital structure for the firms. As shown in figure 1 it requires approximately three years. 


\section{CONCLUSION}

Our findings reveal the factors that influence the capital structure of real estate, property, and construction companies in Indonesia, which are profitability, tangibility, liquidity, size, and NDTS. Based on our regression results, variables profitability, tangibility, liquidity, and size show an opposite relationship with leverage, whereas NDTS has a positive one. However, growth and dividend policies are insignificant. It indicates that growth and dividend policies are not good predictors or determinants of leverage.

The study presents evidence that dynamic model companies possess an optimal target of capital structure and the adjustment speed is determined. The presence of capital structure target is shown through the positive impact leverage on target leverage. In addition, our research finds that in one year, the adjustment speed of firms shows $80 \%$. This indicates that companies adapt to its target rapidly. Lastly, closing the disparity between the current and the targeted capital structure for the firms requires approximately three years.

\section{REFERENCES}

Abdeljawad, I., Nor, F. M., Ibrahim, I., \& Abdul, R. (2013). Dynamic Capital Structure Tradeoff Theory: Evidence from Malaysia. In Proceedings of 3rd Global Accounting, Finance and Economics Conference 5-7 May (Vol. 9, pp. 1-10).

Ameer, R. (2010). Determinants of Corporate Hedging Practices in Malaysia. International Business Research, 3(2), 120-130. https://doi.org/10.5539/ibr.v3n2p120

Arellano, M., \& Bond, S. (1991). Some Tests of Specification for Panel Carlo Application to Data: Evidence and an Employment DETERMINANTS OF CAPITAL STRUCTURE'S ADJUSTMENT
Equations. The Review of Economic Studies, 58(2), 277-297.

Asia Development Bank. (2017). Meeting Asia's Infrastructure Needs. https://doi.org/10.22617/FLS168388-2

Booth, L., Aivazian, V., \& Demirguc-kunt, A. (2001). Capital Structures in Developing Countries. THE JOURNAL OF FINANCE, LVI(1), 87-130.

Brigham, E. F., \& Houston, J. F. (2013). Fundamentals of Financial Management. The Science of Defoaming. https://doi.org/10.1201/b15158-13

Chadha, S., \& Sharma, A. K. (2015). Determinants of capital structure: an empirical evaluation from India. Journal of Advances in Management Research, 12(1), 3-14. https://doi.org/10.1108/JAMR-08-2014-0051

Chang, X. I. N., \& Dasgupta, S. (2009). Target Behavior and Financing: How Conclusive Is the Evidence? The Journal of Finance, LXIV(4), 1767-1796.

Chen, J. J. (2004). Determinants of capital structure of Chinese-listed companies. Journal of Business Research, 57(12 SPEC.ISS.), 1341$1351 . \quad$ https://doi.org/10.1016/S01482963(03)00070-5

Cloyd, C. B., Limberg, S. T., \& Robinson, J. R. (1997). The impact of federal taxes on the use of debt by closely held corporations. National Tax Journal, 50(2), 261-277.

Danso, A., \& Adomako, S. (2014). The financing behaviour of firms and financial crisis. Managerial Finance, 40(12), 1159-1174. https://doi.org/10.1108/MF-04-2014-0098

Deesomsak, R., Paudyal, K., \& Pescetto, G. (2004). The determinants of capital structure: evidence from the Asia Pacific region. Journal of Multinational Financial Management, 14, 387-405. https://doi.org/10.1016/j.mulfin.2004.03.001

Faulkender, M., Flannery, M. J., Watson, K., \& Smith, J. M. (2012). Cash flows and leverage adjustments. Journal of Financial Economics, 103(3), 632-646. https://doi.org/10.1016/j.jfineco.2011.10.013

Fischer, E., Heinkel, R., \& Zechner, J. (1989). Dynamic Capital Structure Choice: Theory and Tests, $X L I V(1), 19-40$.

Flannery, M. J., \& Rangan, K. P. (2006). Partial 
adjustment toward target capital structures. Journal of Financial Economics, 79(3), 469506.

https://doi.org/10.1016/j.jfineco.2005.03.004

Frank, M. Z., \& Goyal, V. K. (2009). Capital Structure Decisions: Which Factors Are Reliably Important? Financial Management, 38(1), 1-37.

Getzmann, Andre, Lang, S., \& Spremann, K. (2014). Target Capital Structure and Adjustment Speed in Asia *. Asia-Pacific Journal of Financial Studies, 43, 1-30. https://doi.org/10.1111/ajfs.12038

Getzmann, André, Lang, S., \& Spremann, K. (2010). Determinants of The Target Capital Structure and Adjustment Speed - Evidence from Asian Capital Markets. Asian Finance Symposium, (March), 1-31.

Graham, J. R., \& Harvey, C. R. (2001). The theory and practice of corporate finance: evidence from the feld. Journal of Financial Economics, 60, 187-243.

Haron, R. (2016). Do Indonesian firms practice target capital structure? A dynamic approach. Journal of Asia Business Studies, 10(3), 318334. https://doi.org/10.1108/JABS-07-20150100

Haugen, R. A., \& Senbet, L. W. (1978). The Insignificance of Bankruptcy Costs to The Theory of Optimal Capital Structure. The Journal of Finance, 33(2), 383-393. https://doi.org/10.1111/jofi.12742

Horne, J. C. Van, \& Wachowicz, J. M. (2008). Fundamentals of Financial Management 13th Edition.

Jalilvand, A., \& Harris, R. S. (1984). Corporate Behavior in Adjusting to Capital Structure and Dividend Targets: An Econometric Study. The Journal of Finance, 39(1), 127-145. https://doi.org/10.1111/j.15406261.1984.tb03 864.x

Keown Jr, A. J., Martin, J. D., \& Petty, J. W. (2017). Foundations of Finance (9th ed.). England: Pearson Education Limited.

Lemma, T. T., \& Negash, M. (2014). Determinants of the adjustment speed of capital structure Evidence from developing economies. Journal of Applied Accounting Research, 15(1), 64-99. https://doi.org/10.1108/JAAR03-2012-0023
Luigi, P., \& Sorin, V. (2009). A Review of Capital Structure Theories. Annals of Faculty of Economics, 3(1), 315-320.

Michael C. Jensen, \& Meckling, W. H. (1976). THEORY OF THE FIRM : MANAGERIAL BEHAVIOR, AGENCY COSTS AND OWNERSHIP STRUCTURE. Journal of Financial Economics, 3, 305-360.

Miller, M. H. (1977). Debt and Taxes. The Journal of Finance, XXXII(2), 261-275.

Modigliani, F., \& Miller, M. H. (1963). Corporate Income Taxes and the Cost of Capital: A Correction. American Economic Association, 53(3), 433-443.

Mota, J. H. F., \& Moreira, A. C. (2017). Determinants of the capital structure of Portuguese firms with investments in Angola, $1-11$.

Myers, Stewart C, \& Majluf, N. S. (1984). Corporate financing and investment decisions when firms have information that investors do not have*. Journal of Financial Economics, $13,187-221$.

Myers, Stwr C. (1984). The Capital Structure Puzzle. THE JOURNAL OF FINANCE, XXXIX, 575-592.

Negara, S. D. (2016). Indonesia's Infrastructure Development under the Jokowi Administration. In M. Cook \& D. Singh (Eds.), Southeast Asian Affairs 2016 (First, pp. 145-165). Singapore: ISEAS-Yusof Ishak Institute. https://doi.org/10.1355/9789812306708-023

Nha, B. D., Loan, N. T. B., \& Nhung, N. T. T. (2016). Determinants of capital structure choice: Empirical evidence from Vietnamese listed companies. Society and Economy, $38(1)$, 29-45. https://doi.org/10.1556/204.2016.38.1.3

Nugroho, H. (2019). THE IMPACT OF GOVERNMENT SUPPORT ON THE PERFORMANCE OF INDONESIA 'S STATEOWNED ENTERPRISES. Tokyo, Japan.

OECD. (2018). Survey Economi OECD Indonesia 2018. OECD Economic Survey: Indonesia@OECD 2018 (Vol. 53). https://doi.org/10.1017/CBO9781107415324. 004

Padrón, Y. G., María, R., Apolinario, C., Santana, O. M., \& Verona, M. C. (2005). Determinant 
factors of leverage : An empirical analysis of Spanish corporations.

Proença, P., Laureano, R. M. S., \& Laureano, L. M. S. (2014). Determinants of Capital Structure and the 2008 Financial Crisis: Evidence from Portuguese SMEs. Procedia - Social and Behavioral Sciences, 150, 182-191. https://doi.org/10.1016/j.sbspro.2014.09.027

Rajan, R. G., \& Zingales, L. (1995). What Do We Know about Capital Structure? Some Evidence from International Data. THE JOURNAL OF FINANCE, L(5), 1421-1460.

Ramjee, A., \& Gwatidzo, T. (2013). Dynamics in capital structure determinants in South Africa. Meditari Accountancy Research, 20(1), 5267. https://doi.org/10.1108/10222521211234228

Rawley Thomas, \& Gup, B. E. (2010). The Valuation Handbook. (W. F. Mahoney, Ed.). New Jersey: John Wiley \& Sons.

Ross, S., Westerfield, R., \& Jaffe, J. (2008). Corporate Finance. McGraw-Hill Irwin. https://doi.org/10.1108/15265940510633505

Rozeff, M. S. (1982). GROWTH, BETA AND AGENCY COSTS AS DETERMINANTS OF DIVIDEND PAYOUT RATIOS. Journal of Financial Research, V(3), 249-259.

Sangeetha, M. M., \& Sivathaasan, N. (2013). Factors Determining Capital Structure: A Case study of listed companies in Sri Lanka. Research Journal of Finance and Accounting, 4(6), 236-247.

Sayılgan, G. (2006). The Firm-Specific Determinants of Corporate Capital Structur: Evidence from Turkish Panel Data. Investment Management and Financial Innovations, 3(3), 125-139.

Serrasqueiro, Z., Matias, F., \& Salsa, L. (2016). Determinants of capital structure: New evidence from Portuguese small firms. $A$ Multidisciplinary E-Journal, (2016), 13-28.
https://doi.org/10.18089/DAMeJ.2016.28.2

Soekarno, S. (2014). Innovative Model in Determining the Capital Structure Target in State Owned Enterprises. In D. Larso, D. C. Lantu, \& W. Dhewanto (Eds.), Indonesia International Conference on Innovation, Entrepreneurship, \& Small Business (pp. 145-154). Bali: CIEL SBM ITB.

Soekarno, S., Kitri, M. L., \& Utomo, S. (2016). Capital structure determinants and the speed of adjustment towards capital structure target : evidence from Indonesian state-owned enterprises. Int. J. Monetary Economics and Finance, 9(4), 4-6.

Sofat, R., \& Singh, S. (2017). Determinants of capital structure: an empirical study of manufacturing firms in India. International Journal of Law and Management, 59(6), 1029-1045. https://doi.org/10.1108/ijlma-052016-0051

Syahara, Y. R., \& Soekarno, S. (2015). THE EXISTENCE OF TARGET CAPITAL STRUCTURE AND SPEED OF ADJUSTMENT: EVIDENCE FROM INDONESIAN PUBLIC FIRMS. In Proceedings of International Conference on Management Finance Economics (pp. 191199).

Thi, N., Nhung, P., Lien, N. P., Thi, D., \& Hang, T. (2017). Analyze the Determinants of Capital Structure for Vietnamese Real Estate Listed Companies. International Journal of Economics and Financial Issues, 7(4), 270282.

Titman, S., \& Wessels, R. (1988). The Determinants of Capital Structure Choice. The Journal of Finance, XLIII(1), 1-19.

Wiwattanakantang, Y. (1999). An empirical study on the determinants of the capital structure of Thai firms. Pacific-Basin Finance Journal, 7, 371-403. 